\title{
WASHBACK OF AN ENGLISH ACHIEVEMENT TEST ON TEACHERS' PERCEPTIONS AT A VIETNAMESE UNIVERSITY
}

\author{
Dinh Minh Thu* \\ Haiphong University, \\ 171 Phan Dang Luu, Kien An, Hai Phong, Vietnam
}

Received 31 January 2020

Revised 20 May 2020; Accepted 29 May 2020

\begin{abstract}
Research on washback, i.e. test impacts on teaching and learning in class, of high-stake English tests is prevalent. Little attention has, however, been paid to washback of an English achievement test (EAT) albeit its highly practical significance including reporting and improving teacher effectiveness right in a programme in a specific context (El-Kafafi, 2012; Antineskul \& Sheveleva, 2015). The present paper aims to explore teachers' perceptions of the teaching contents under the influence of an EAT which steps up to an English Proficiency Test - PET (or B1 level equivalent) for university undergraduates in Vietnam as required for graduation by Vietnam's Ministry of Education and Training (MOET). The EAT, mirroring the PET, was designed to expect positive washback in the course English 2. The research tools were interviews with four teachers teaching the same English course. Each teacher was interviewed twice at two different time points so that their temporal developmental cognition of the EAT could be recorded. The findings revealed the heavy impact of the test on teachers' perceptions of their teaching contents. Two dominant points were (1) all the participants thought the course primarily served the EAT orientation, particularly in the test format and the linguistic input, and (2) the teachers should strictly follow the textbook as the major instructional source. There existed a mismatch between the university's purpose of enhancing the students' communicative ability and the teachers' perceptions. Differences in the teachers' backgrounds entailed their diverse perceptions. The study provides a reference case for the interested readers in and beyond the researched context.
\end{abstract}

Keywords: washback, English achievement tests, teachers' perceptions

\section{Introduction}

Language testing and assessment has emerged as an issue of due concern for its complex and pivotal nature in language education all over the world in recent decades. The 1990s recognized it as a mainstream of applied linguistics (Bachman, 2000) for its substantial contributions to innovative educational practices towards individual and

\footnotetext{
Tel.: 84-912362656
}

Email: minhthu.knn.dhhp@gmail.com societal demands (Alderson \& Banerjee, 2002; Bachman, 2000; Hughes, 2003; Messick, 1996; Onaiba, 2013; Shohamy, 1993). Such countries as China, Japan, Taiwan and Vietnam always highly appreciate the testing culture. In the epoch of globalization, Vietnam places more emphasis on the English language training in the national education system. The National Foreign Language (NFL) Project 2020, extended to 2025, requires innovation on learning, teaching and assessment of foreign languages at all levels. Vietnamese non-English-majored?? 
undergraduates are required to reach a minimum of B1 (Independent Users), which pushes a large number of undergraduates to graduation delays because of the high failure rates in such graduation tests (Cao, 2018; Ha, 2016; Huy Lan, 2019; Thuy Nhan, 2016; Vu, 2016). Those at the researched university are of no exceptions. TOEIC, followed by simulated VSTEP, was applied but those tests seriously challenged the students. The university has recently shifted towards PET orientation, expecting more confidence from teachers and students and better success in the training. In other words, positive washback was expected like in Saif's study (2006) on test effects, i.e. washback, that turns dominant with "significant implication regarding test validation and fairness" (Cheng \& Curtis, 2012, p. 440). In fact, research on washback of English language tests in the Vietnamese context has been conducted on either the international tests (Barnes, 2016b, 2017; Nguyen, 1997; Thuy Nhan, 2013; Tran, 2016) or national tests (Bùi, 2016; Nguyen, 2017a; Nguyễn, 2017b; T Nguyen, 2017; Nguyen, 2018). However, little research of this type has been recorded in Vietnam on a single university's internally-developed test in an attempt to meet MOET's requirement of tertiary students' English language proficiency. The current study will fill the gap by investigating the washback effects of an English achievement test (EAT) at a Vietnamese university on teachers' perceptions of their teaching contents. Teachers' perceptions normally attract researchers because they are considered a driving force to teachers' practices (Liauh, 2011; Pajares, 1992; Wang, 2010; Zeng, 2015). Teachers are selected as the informants for the research on the basis that teachers are facilitators or triggers of the washback process (Antineskul \& Sheveleva, 2015; Bailey, 1999; Liauh, 2011; Onaiba, 2013; Richards \& Lockhart, 2007; Tsagari, 2011; Wang, 2010). The EAT follows the PET format and its contents cover students' learning achievements within the course English 2. The training and assessment aim to familiarize students and teachers with the contents and formats of PET. The full PET exam will be the measurement tool for undergraduates' English proficiency as a condition for graduation.

A research question is posed as follows:

How does the EAT exert its washback effects on teachers' perceptions of their teaching contents at a university in Vietnam?

A qualitative approach with interviews was exploited to investigate the EAT washback on teachers' perceptions of their teaching contents. An overview of washback concepts, achievement tests, teachers' perceptions, and results from relevant empirical washback research initiated the methodology and the findings of the current study.

\section{Literature Review}

\subsection{Washback concepts}

Washback is frequently mentioned beside backwash, consequences and impact. Washback and backwash refer to the same phenomenon (Cheng et al., 2004; Hughes, 2003) while it is not fully synonymous with consequences and impact (Bachman \& Palmer, 1996; Cheng et al., 2015; Pan, 2009). Consequences belong to general education measurement, pertaining to the matter of validity. Washback and impact, on the other hand, are narrowed down to the area of applied linguistics. Washback can be seen as a part of test impacts limited in the classroom (Alderson \& Wall, 1993; Bachman \& Palmer, 1996; Hughes, 2003) or spread its effects beyond the school (Alderson \& Banerjee, 2001, 2002). The current research concerns washback in its narrow sense, limited to individuals in the classroom context.

Buck (1988, p. 17, cited in Bailey, 1999) was the first researcher to introduce washback as a "natural tendency for both teachers and students to tailor their classroom activities to the demand of the test" or "the influence of the 
test on the classroom". Other general concepts of washback can be provided as "the effect of testing on teaching and learning" (Hughes, 2003, p.1); "the impact of external language tests to affect and drive foreign language learning in the school context" (Shohamy, 1993, p. 153); "the direct impact of testing on individuals" (Bachman \& Palmer, 1996, p. 30) or the force for "teachers and learners to do things they would not necessarily otherwise do because of the test" (Alderson \& Wall, 1993, p.1). If these definitions sound fairly general, specific factors are involved in the coming ones. Cohen (1994, p. 41) claims washback clarifies "how assessment instruments affect educational practices and beliefs". Messick (1996, p. 4) considers washback "the extent to which the introduction and use of a test influences language teachers and learners to do things they would not otherwise do that promote or inhibit language learning".

Other researchers extend the definition by identifying factors and participants involved in the change. Pierce (1992, p. 687), for example, adds washback as "the impact of a test [that] has on classroom pedagogy, curriculum pedagogy, curriculum development and educational policy". Pearson (1988, p. 7) states washback from the psychological perspective that "public examinations influence the attitudes, behaviours, and motivation of teachers, learners, and parents, and because the examinations often come at the end of a course, this influence is seen working in a backward direction, hence the term, washback". Nonetheless, he admitted that this direction can operate forward since tests can lead teaching and learning. Bullock (2017) states very clearly that washback effect is "the influence of the format or content of tests or examinations on the methods and content of teaching and learning leading up to the assessment". It is noted that the effects are only washback if they can be linked to the introduction and use of the targeted test (Messick, 1996).

The above analysis yields a clear shape of washback which means the test influence on teachers' psychological mechanism and actions to reach the educational goals. This research conceptualizes washback as the classroom impact of a test on teachers' and learners' perceptions and actions toward the teaching, learning and testing goals. Washback can operate in two ways, either positive or negative (Pan, 2009). A test has a beneficial washback if it enhances teaching and learning, especially improving students' language competence. By contrast, deleterious washback is seen if teaching and learning heavily stick to the test rather than true language ability. In the washback process, teachers are "the 'front-line' conduits for the washback processes related to instruction" (Bailey, 1999, p.17). They are supposed to introduce tests to students and accompany them to reach the goal. The present research endeavors to examine the washback mechanism of the EAT to teachers at a Vietnamese university to figure out how the test exerts its influence on their perception of the teaching contents in their English class.

\subsection{Achievement tests}

Tests can be categorized into achievement and proficiency (Hughes, 2003; McNamara, 2000; Brown \& Abeywickrama, 2010; Brown, 2013, Bachman, 1990). While proficiency tests are theory-based, i.e. testing test takers' "can-dos" in real life according to a given language proficiency theory, achievement tests are syllabus-based, i.e. assessing the curriculum objectives (Bachman, 1990; Bailey, 1998; Brown, 2013; Brown \& Hudson, 2002; Cheng, Watanabe \& Curtis, 2004; Hughes, 2003). Within this research scope, achievement tests are reviewed in terms of its role, definition and types.

Achievement tests play a central role in assessing students' accomplishment by the end of a unit or a programme (Brown \& Abeywickrama, 2010, p. 9; McNamara, 2000, p. 12; Walberg, 2011,p. 2). Its principal purpose is to announce the standard achievement for all stakeholders like students, teachers, 
authorities, or parents from which appropriate decisions pertaining to learning and teaching reforms or mastery certification are made (Hughes, 2003; Brown \& Abeywickrama, 2010). By definition, achievement tests evaluate the fulfilled amount of course contents pertaining to the course objectives (Hughes, 2003; McNamara, 2000; Brown \& Abeywickrama, 2010; Brown, 2013). Hughes (2000, p.13) classifies achievement tests into two types: final and progress ones in terms of the administration time. He provides sound arguments on the final achievement test approaches. Final achievement tests, happening at the end of the course, can follow either the syllabus content or the objectives. The syllabus-content-based approach appeals fair to students since tests cover what students have learned in the course. Nonetheless, if the school has unqualified syllabus and tests, the students' language ability that is expected to be measured with that achievement test can be misleading. For example, the old Vietnamese K12 English course books exclude listening, a radical element of communicative language. Hence, a high score in the English test, which is deficient of the listening test, cannot signify the score gainer's true language ability. The second approach aligns the test content with the course objectives. In this way, course objectives are made explicit to all course designers, teachers and students. Hughes (2003) believes that final achievement tests sticking to course objectives can interpret students' language ability better, therefore more positive washback can be created. However, choosing appropriate materials for established objectives is demanding. Plus, course objectives are more challenging to reach than course contents, which can lead to students' dissatisfaction of test results. This approach results in the blur between achievement tests and proficiency tests. Hughes (2010) argues, "If a test is based on the objective of a course, and these are equivalent to the language needs on which a proficiency is based, there is no reason to expect a difference between the form and content of the two tests" (p. 14). Final achievement tests are usually standardized since all the tests follow the same structures. Test writers and developers should ground on specific course objectives to design tests. Besides final achievement tests of the summative meaning, progressive achievement tests of the formative purpose are popular in language classrooms to measure to what extent students progress toward the end-course achievement. This achievement test runs into two streams. The first one administers final achievement tests repeatedly to expect a score rise as indicators of progress. This is blamed to be impractical, especially when students have insufficient syllabus exposure. The second one aims at shortterm objectives, which matches the limited amount of the content students have learned. Feedback or reflection is fairly important for both teachers and students to adapt their teaching and learning correspondingly.

The achievement test in the current research, the EAT, is characterized as the second type which intends to gauge the sum of knowledge and skills non-English majored freshmen have attained in the course English 2 in the second semester. Generally, the EAT format mirrors the PET format, despite the reduction of the part number in each paper in the EAT. The overall aim of the test is to help the teachers make the students familiarise with the real PET format and samples, which they will encounter in their English graduation examination at the researched university. The two tests share three major common points. Firstly, both test students in four skills, reading, writing, listening and speaking. Secondly, both have a balanced weighting of $25 \%$ each part. Thirdly, the purpose of each paper in the two tests seems to be the same. According to B1 Preliminary Exam Format, the PET reading paper requires test takers to show they "can read and understand the main points from signs, newspapers and magazines, and can use vocabulary and structure correctly". The writing paper aims to assess 
their ability of using "the structure correctly and produce communicative messages and informal letter/story". Their ability "to follow and understand a range of spoken materials including announcements and discussions about everyday life" should be shown in the listening paper. In the speaking part, they are expected to "show the ability to follow and understand a range of spoken materials including announcements and discussions about everyday life, then to take part in conversations by asking/answering questions and talking, for example, about your likes and dislikes". The same purpose is set for the EAT although these abilities are measured in the restricted topics given in the course English 2 because while the PET is a proficiency test, the EAT is an achievement one.

Paker (2012) investigates washback of test items in four language skills of the achievement tests in preparatory classes in 13 Turkish schools of Foreign Languages. Test items are selected to analyse, aiming at potential washback. To this extent, the research fails to address washback from participants' perspective, especially from the teachers'. The current study aims to fill into the gap by investigating washback of an English achievement test to teachers' perceptions of the course objectives and contents at a Vietnamese university.

\subsection{Teachers' perceptions in washback research}

Perception is defined in the Cambridge Dictionary as "a belief or an opinion" or "an understanding". According to Buehl \& Fives (2009), there is inconsistency in defining teachers' beliefs. While Green (2013) and Richardson (1996) distinguish beliefs from attitudes and knowledge, Borg (2003) and Pajares (1992) define beliefs as knowledge, perceptions and attitudes. Then, perceptions can be understood through the definitions of beliefs. Rokeach $(1969$, p. 113 as cited in Skott (?, p. 17) sets beliefs as an "integrated cognitive system" or "any simple proposition ... inferred from what a person says or does, capable of being preceded by the phrase 'I believe that ...". Pajares (1992, p. 316) defines beliefs as an "individual's judgment of the truth or falsity of a proposition, a judgment that can only be inferred from a collective understanding of what human beings say, intend, and do". Richardson (1996, p. 102) names beliefs as "a subset of a group of constructs that name, define, and describe the structure and content of mental states that are thought to drive a person's actions". Perceptions belong to these constructs.

In washback research, teachers' perceptions are grounded on the label "attitudes", "feelings" (Mahmoudi, 2013; Tsagari, 2011, pp. 434-435), "beliefs" (Wang, 2010), "understanding" (Cheng, 2004; Hsu, 2009). Antineskul and Sheveleva (2015) link teachers' perceptions to such terms as "attitude", "think", "like", and "know" (pp. 8-12). Onaiba(2013,p. 56) accredits perception washback to feelings, beliefs, attitudes toward the test. Only Mahmoudi (2013) mentions perceptions and attitudes separately from the title of his research, and only Green (2013) talks about beliefs, not perceptions. Green (2013) raises specific questions on teachers' beliefs about teaching and testing. Regarding teaching, they are teachers' beliefs of effective teaching strategies and their compatibility with test demands, of test preparation challenges and of "local precedents" for that preparation. In terms of a specific test, the author is concerned about teachers' beliefs of their familiarity with the test, of its use and role. Cheng (2004) and Hsu (2009) are two researchers who best specify teaching aspects under the test influence. Both Cheng (2004) and Hsu (2009) propose aspects of classroom teaching in teachers' perceptions, including test rationales and formats, the teaching methods and activities. Cheng (2004) extends his concerns to workload and teaching difficulties under test impacts, while Hsu (2009) is interested in teachers' using mock exams and course books and students' learning strategies and activities. 
From the above review, teachers' perceptions under the influence of a test denote how teachers feel, think about, believe and understand that test and their classroom teaching practices. Nonetheless, it would be reasonable to exclude test formats in the current study of teachers' perceptions since test factors should be seen as triggers to classroom practices rather than practices as Cheng (2004) and Hsu (2009) discuss. This view is in accordance with Shih's (2009) framework on teachers' factors in washback mechanism. Washback to teachers' perceptions, according to Dinh (2019), ranges from teaching contents, methodology and professional development. The present research is limited to the first component of what teachers think they teach under the influence of the EAT.

\subsection{Empirical washback research on} teachers' perception of teaching contents at the tertiary level

Publications reveal that teachers perceive washback to teachers' perceptions of teaching contents in two opposite trends, either a match or a mismatch between the test contents and the taught contents.

Wall and Horak (2011) report the washback effects of the TOEFL iBT on the teaching contents positively from European higher education institutions. Textbooks are updated, informing both teachers and students of the content of teaching, learning and testing. They even orient their classroom behaviours. VSTEP in Vietnam (Nguyen, 2017) exerts positive effects on teaching sources. The author appreciates the material called "Learners' Outcomes and Profile", which specifies students' required knowledge and skills in each learning stage and the supplementary materials of grammar points and vocabulary banks for each level. The teachers in her study believe that the materials and skills taught in the courses for VSTEP can support students to cope with any test types. This is an idea which has not appeared in other studies in this review. In addition, the participants in Saif's (2006) study believe that the textbook strategies well enhance students' learning of presentation skills.

On the other hand, Liauh's (2011) research on the washback effects of the Exit English Examination (EEE) in Taiwanese universities reports teachers' beliefs in the need of further provision of good quality teaching materials for the students' self-study for their EEE. They ask for additional English courses in the curriculum to increase their students' passing rate in the test. Outdated course books are used in the case of the test for Business English Certificate (BEC) in Russia (Antineskul \& Sheveleva, 2015); therefore, teachers need collaboration to enrich and update their teaching materials although sometimes the relationship is hard to be established. The two authors have reported the discrepancies between the course contents and the students' needs. Teachers have to face students' command of their present practical skills rather than teachers' preparation for their long-life skills. For example, a student just needs to learn to write the letter of offer instead of the letter of complaint because they are in need of it for the moment (Antineskul \& Sheveleva, 2015, p.11). Teachers have to explain and balance the want and the need. In Vietnam, Thuy Nhan (2013, p.38) also adds the mismatch between the curriculum and the contents required for an exit gate-keeping test of TOEFL. Those authors expect the correlation between the materials employed in the teaching process and the contents measured the product. Nonetheless, Hsu (2009, pp.136-137) reports a group of Taiwanese teachers think tertiary English language teaching should serve the world of work, not the test only; therefore, their textbook choice is not impacted by the test policy. In addition, they think students need various sources of materials to meet the demand of a proficiency test. They use textbooks, language laboratory, test-oriented materials and other authentic materials of magazines, newspapers, radio and television, 
with textbooks being dominant. Wall \& Horák (2006) are in line with these authors. The teachers in their research, while agreeing on in-class textbooks, encourage students to practice with authentic materials. Teachers in Tran's (2016) research at a Vietnamese university agree with those in Hsu's (2009) and Wall \& Horák's (2006). Although the content of the textbook is not directly relevant with that of TOEIC, which serves as a gatekeeping test, the teachers think highly of its relevance to the world of work after students' graduation.

In most of the previous studies, teachers believe that it is necessary to have the correlation between the taught contents and the test contents and that they both should back up students' language ability at work. These results are mainly extracted from the high-stakes tests. The question on how teachers believe their taught contents under the influence of a low-stakes test will be answered in this study.

\section{Methodology}

\subsection{Setting}

The research was conducted at a university in the North of Vietnam. English is taught as the dominating foreign language to the undergraduates. Generally, the students at the university were of low English proficiency. Under MOET's requirement, the institution adopted the two-languageskill TOEIC, and then the four-language-skill simulated VSTEP as the major measurement instruments of the undergraduates' foreign language condition for graduation from 2010 to 2018. Nonetheless, these two test types challenged the students at high failure rates. The situation motivated the shift towards the four-language-skill PET instead. Prior to the formal PET examination, 2 courses English 1 and English 2 are delivered, in which the students' accomplishment was gauged with the final EAT in the shortened form of the PET.
The university's leaders anticipated beneficial washback to teaching and learning.

\subsection{Participants}

Four female teachers teaching English 2 having the final EAT at a university in the North of Vietnam participated in the research on the basis of purposive sampling. Teacher factors, an important variable in washback research (Alderson \& Wall, 1996; Read \& Hayes, 2003; Shih, 2009; Wantanabe, 1996) were collected via an interview. Teacher 1 is the Head of the Division of English for Specific Purposes where English 2 in the current research is designed and implemented. She has six years of work experience in the Division. Two other teachers are not in the leadership positions but they are experienced. Teacher 2 has been working as an English teacher in the Division for 15 years, and Teacher 3 has 18 years of working experience. Teacher 2 is the person who introduces the course book and is involved in developing the EAT. Teacher 4 is a two-yearexperienced teacher. All the teachers report that they are familiar with the contextual factors and the test factors. Except Teacher 3 who shows a normal degree of commitment to teaching and student success in the test, all the others own high involvement. It is noted that washback existence was ever questioned by Alderson and Wall (1993), but Watanabe (2004, p.28) suggests a way to track its evidence. According to him, washback comes into existence if (1) the same teacher teaches the exam-preparation class differently from non-exam-preparation class, and (2) different teachers teach different classes of exam preparations the same. All the participants are involved in teaching different classes with the same programme, which promises washback. The EAT measures students' final achievement. The course book selected is Complete PET.

\subsection{Instruments}

Teachers' perceptions "cannot be directly observed or measured but must be inferred from what people say, intend, do-fundamental 
perquisites that educational researchers have seldom followed" (Pajares, 1992, p.314). Creswell (2009) claims that an effective means to collect information regarding beliefs, attitudes, perceptions and behavior is a survey or an interview. The current study exploited the interview instrument to reach the research aim. The semi-structured interviews were designed. The validity and reliability of the instrument were piloted with two nonparticipant teachers in the same context. The interviews used Vietnamese as the channel to make the respondents voice their thoughts fully in the most confident manner. Le (2011) believes that two interlocutors of the same mother tongue would feel more comfortable when communicating in their own common language.

The interviews of the teachers' perceptions of their teaching contents based on a guideline (Appendix) including three parts of course objectives, teaching sources and teaching topics. The course objectives could be represented by three questions concerning each teacher's actual teaching objectives and the syllabus and the test objectives. The researcher sought teachers' beliefs of their teaching sources by asking four questions on teachers' must-use materials and shoulduse materials together with their rationales. Teaching topics were found via the answers on four questions about what topics must be and should be included in the course.

\subsection{Data collection and analysis}

The pilot interviews took place with the non-participant teachers to check the transparency of the meanings of the questions. A recorder was used to record the data. After the pilot interview, some questions were deleted, some added and some re-worded for clarity and richness. For example, question one in the pilot interview is "How do you think of the objectives of Course English 2?" was modified into a set of detailed question like in the Appendix. Then, the official interview took place with the individual participating teachers. Nonetheless, the interview contents were still open to changes. The first interviews were transcribed and coded for the analysis. Only relevant data is translated into English. The convention of $T 1$, Int 1, p.1, for example, signified an excerpt taken from Teacher 1, Interview 1, Page 1. The sign " $<>$ " referred to the researcher's clarification. Supplementary interviews were made to clarify several ambiguous points, thus seeking deeper data. Patterns were depicted from the analysed data.

\section{Findings and discussion}

The findings from the data collection and analysis are presented in themes, which allows both individual cases and cross-cases to be seen (Duff, 2008). The study aims to see how the EAT impacts the teachers' perceptions of their teaching objectives. Since the EAT mirrored the PET, these tests were mentioned interchangeably here and there. Overall, the test exerted its significant impacts on the teaching objectives most.

\subsection{The washback of the EAT on the teachers' perceptions of the teaching objectives}

\subsubsection{PET/EAT orientation}

All the four teachers agreed that the course objectives should be set to equip the students with the PET/EAT linguistic knowledge and format input so that the students could be successful in the exam. It is noted that PET is an umbrella test for EAT in the research case. In terms of the linguistic inputs, vocabulary, grammar and pronunciation are three principal components. However, all the interviewed teachers were concerned about vocabulary and grammar rather than pronunciation. Only Teacher 1 and Teacher 2 were concerned about teaching pronunciation as one subaim. The test approach was also expressed in the teachers' view of one course objective as providing the test skills and test format. Teacher 1 was interested in the provision of the test format most with 41 times mentioning this (see Table 1). She believed that the 
students could be more confident in the exam if they were exposed to the test format as much as possible, then this increased their passing rate. She was the only one explicitly expressing the need of providing the test sources for the students. This can be explained from her background as a head teacher who is experienced and has more responsibility of the students' exam success. Teacher 4, a novice, owned a higher frequency of thinking about the role of test source provision than Teacher 2 and Teacher 3.

"The common objectives of the course is to provide the students with the knowledge of grammar and vocabulary together with training the test skills in the orientation of the graduation test of the international PET' (T1, Int1, p.1).

Teacher 2 agreed that the course aim is to "provide the students with basic knowledge from elementary to pre-intermediate"; therefore, the teachers should "cater grammar, vocabulary and test skills which practically serves PET tests of B1 level as the graduation test" (In2, p.1). She believed that the teachers' duty is to "help students acquire the knowledge in the course... and how to help students pass the EAT" (Int2, p.2). In the similar vein, Teacher 4 , the novice, expressed her view of the course objectives as "serving the students" passing the exam in the PETformat" (Int1, p.2; Int2, p.3). It is interesting that she regularly talked about the word "exam advice" which is part of the book for any test tasks throughout the interview. The phrase did not occur in the first interview but the second one when she really became more familiar with the book while teaching.

By comparison, while Teacher 4 had six times mentioning her role in "helping students to pass the exam" in two interviews of her perceptions, her words did not specify any "PET" or "EAT" despite the general word "test".

Students' passing the exam was obviously stated as the main goal of the course. Learning vocabulary, grammar, pronunciation, test tasks all served that goal. The research case was a little bit unique when the EAT was strongly affected by the PET as a graduation test later for the students.

\subsubsection{Communicative enhancement}

Communication, either in the spoken or written form, is the end of language learning. The updated English 2, which has the EAT to measure its effectiveness, was supposed to increase the students' communicative competence. A majority of the bachelors from the researched university face the problems of using English effectively. That decreased their professional opportunities, affecting the university's reputation. The data will reveal whether this expected positive washback did take place.

Surprisingly, Teacher 1 did not state her view about it while other teachers, especially Teacher 2 thought highly of one course aim as improving students' communication skill now and for the future. She stated, "The course English 2 mainly aims at equipping students' communicative competence not only now but in the future" (Int2, p.1), or "The teaching process has to improve students' communication skill' (Int2, p.10). She was aware of the university policy, which "requires the communicative teaching approach" so that "I think we have to teach the students to communicate with teachers, with friends, with the outsiders (Int2, p.1). Teacher 3 echoed the view when she thought that "has a practical purpose which is to improve students' communication skills through speaking and writing" (Int.1, p.1). Productive skills were mentioned clearly in her speech. Plus, she believed in the "balance between the test purpose <students' passing the exam> and the communication purpose" (Int2, p.13). According to Teacher 4, the university policy asked her to teach in the communicative approach (Int1, p.1) and she balanced between the aim of supporting the students in the exam and training their English communication (Int2, p.13).

The interview outcomes revealed that Teacher 2 and Teacher 4 considered communication purpose even more important 
than test passing purpose. Teacher 4 as a novice seemed to be dependent on the university policy while no other teachers mentioned that administrative level.

\subsubsection{Others}

In the interviews, other course purposes emerged from the teachers' perspective. A very different point which other teachers but Teacher 2 did not care obviously was teaching and learning effectiveness. She stated,

"The course objective, like other courses, includes evaluating teachers' teaching quality and students' learning quality. I am interested in knowing the results of my teaching and students' learning." (T2, Int1, p.1)

"The effectiveness of my teaching can be expressed via students' happiness in class, their participation in class, their test scores in the exam.... The students' effectiveness is the same, especially their passing scores." (T2, Int2, p.1)

Looking back at her background, she is a key teacher in the course, introducing the course book, developing the EAT, showing a high commitment to students' success in the course. It is reasonable when she set a course aim as measuring the training efficiency. This point is very different from other teachers' in this and other washback research.

Table 1. Frequency of the teachers' words related to the teaching objectives

\begin{tabular}{|c|c|c|c|c|}
\hline Words & T1 & T2 & T3 & T4 \\
\hline PET/EAT vocabulary & 17 & 11 & 4 & 3 \\
\hline PET/EAT grammar & 7 & 14 & 3 & 5 \\
\hline PET/EAT pronunciation & 2 & 3 & 0 & 0 \\
\hline PET/EAT test skills & 4 & 7 & 0 & 4 \\
\hline PET/EAT format & 41 & 1 & 1 & 3 \\
\hline PET/EAT sources & 3 & 0 & 0 & 0 \\
\hline Communicative enhancement & 0 & 8 & 2 & 2 \\
\hline Teacher effectiveness measurement & 0 & 1 & 0 & 0 \\
\hline Learner effectiveness measurement & 0 & 1 & 0 & 0 \\
\hline TOTAL & 74 & 46 & 10 & 17 \\
\hline
\end{tabular}

Course objectives are considered the triggers of teachers' teaching. According to Saif (2006, p.28), the course objectives are based on the test objectives and the test components. As stated in the literature review, the EAT aims to measure the students' language ability achievement at the end of the course with the test instrument of an imitation PET of four language skills. Furthermore, the EAT familiarizes the students with the PET graduation test at the studied site. Linguistic input is the means, not the end of the course and the test objectives. Nonetheless, the interview results revealed that the teachers highly appreciated grammar and vocabulary, which were explicitly stated in only the writing skill, not in the other three skills. Communication purpose was openly stated by Teachers $2,3,4$, especially by Teacher 2 , who regularly showed her high commitment to her teaching in both the teacher background interview and teacher perception ones. The teachers' sharing thought of knowledge and test skill/format provision in this research was in line with Nguyen (2017) who studied washback of VSTEP to teaching at another Vietnamese university. Moreover, the teachers thought they should combine the course objectives and the test objectives together. Teacher 1 and Teacher 3 believed that these two sets of objectives were the same and drew equal attention. Nonetheless, Teacher 2 and Teacher 4 were more favourable of the course objective of communicative ability enhancement as stated at the university. They believed the course objectives were actualized in every lesson. A salient summarized point from the finding was that Teacher 1 as a leader 
has 74 times mentioning the word pertaining to the course objectives, followed by Teacher 2 and Teacher 4 . It can be interpreted that the teachers of more accountability will be more aware of their teaching goal.

\subsection{The washback of the EAT to the teachers' perceptions of the teaching sources}

Regarding teachers' perspectives of the course sources, the course book and the supplement materials were studied in relevance to the teachers' evaluation of the relationship between the course book and the EAT.

\subsubsection{Course book}

As decided by the leadership, the course book selected was Complete PET which received all the teachers' positive attitudes. English 2 was redesigned so the book was used for the first time.. Teacher 1 and Teacher 3 thought the book "interesting". They appreciated its good features including clear explanation, good application, and exam advice. Through two perspective interviews, Teacher 1 agreed that the new course book helped the students "approach grammar, vocabulary and pronunciation which are very basic, and it provides them with <test $>$ skills, especially the test format" (Int2, p.1). She added,

"...a good point in the book is grammar. It is very clear. It is explained, especially in the context. In the test format, grammar is not explicitly stated in writing or reading; however, the exercises $<$ test tasks $>$ are closely relevant. $<$ so that the book $>$ helps students to have a firm background. .... It is interesting that the grammar points were integrated in the topic... and the way they $<$ the book $>$ explains... It serves reading and writing... For example, sentence transformation... the present perfect and the past simple... there is the transformation.... the book clearly explains the difference between two tenses... And in the subsequent part, there is application, for example, for task 1 to rewrite the sentence... how to rewrite the sentence..." (T1, Int2, p7-8)

There was a growth in the teacher's belief of the course book. The second interview showed Teacher 1's deeper understanding of the book content and its application to the course and the test purposes. Grammar, vocabulary, test skills, test formats were frequently mentioned. Teacher 2 became aware of the "exam advice" in the book. She compared the book Complete PET with the book New English File which was used in the previous course English 2. It seems that the second interview conducted when the teacher was more familiar with the book increased her specific comments about the book quality. She was interested in the book grammar points, the link between grammar and its application in the test skills.

In the same vein, Teacher 4 claimed the book "gives detailed <course and test> objectives and orientate reading, writing parts for the students" (Int2, p.2). Her subsequent perception affirmed that point:

"Complete Pet is reasonable, suitable to the students. It is classified into four skills, listening, speaking, reading and writing. And, in each skill, there is the phrase Exam Advice. The listening part has an Exam Advice box too ... And the reading has Exam Advice, the students can see what they should do." (Int2, p.3, 4)

Teacher 4 was interested in the "exam advice" in the book. She compared the book Complete PET with the book New English File which was used in the previous course English 2. The previous book "does not have the Exam Advice to help the students... It made students self study, so they could not know how to cope with the lesson and the test tasks." (Lan, Int2, p.4). Differently from the experienced teachers, Teacher 4 with her novice role needed the exam advice to guide her students clearly in her lessons.

By comparison, Teacher 2 and Teacher 3 thought the book contained the whole necessary information and they used the book as a compulsory source. Teacher 4 said, "the Complete PET is rather long and fairly contains all four skills... and activities... test tasks" (Int2, p.4). 
Moreover, Teacher 4 stated that she used the course book as "the mutual agreement in the Division" (Int2 p.2) and "the leader's requirement" (Int2, p.3). She and other teachers in the Division agreed that the book could "classify the knowledge and supply a standard B1 format for students" (Int2, p.2). She valued the book in helping the students pass the EAT (In2, p.3).

Once again, the novice teacher was more likely to be led by the policy. When asked whether the test impacted the teaching or vice versa, she said, "we have to decide the test first and then find out a suitable coursebook to teach students." (T4, Int2, p.5). Regarding washback research, a question that may be raised is whether the tail (the test) walks the dog (the syllabus and the teaching). Teacher 4's answer contributes to the rationale of washback research, which means the test can affect backward as Hugh (2003) defined this term. Teachers' commitment to teaching and student success seems to be a variable to the frequency of the phrase "Complete PET". The frequency in the teachers' perception is presented in Table 6 in the subsequent part.

\subsubsection{Supplement materials}

It is reasonable to say that if the EAT merely gauges the students' learning outcomes in a programme, one course book can be sufficient. Nevertheless, it takes a further role of equipping students with the PET sources preparing for a graduation test. Hence, other PET test series and the like are supposed to be present in the data bank.

Surprisingly, while Teacher 1 stated that the course aimed to provide the PET sources (see 4.2.1.2), she only appreciated the textbook in the second interview.

"Actually, I think <supplementary materials are $>$ necessary. However, the heavy number of lessons and knowledge prevents it. The workbook is enough because its content is close to what students need to learn. However, as you know, ... Actually the students are of mixed abilities... so we want to provide the students with more of test format, mock tests... in reality, many feel difficult, so I only used the classwork. Those books $<$ PET tests $>$ I don't check in class but require them to do at home." (Int2, p.4-5)

She called out four practical reasons for the little use of supplementary materials: students' low proficiency, limited course time, large classes and students' limited interests. Teacher 2 shared the common view of the heavy reliance on the course book. She said, "I am attracted to the PET reference sources for example PET tests from 1 to 8 " (Int2, p.4) and "Other materials only add more tasks for students' practice. No other course books should be exploited" (Int2, p.6).

Teacher 3 and Teacher 4 showed the change in their perception of using the textbook and the supplement materials. In the first interview, Teacher 3 (Int1, p.4) was worried about time limit while Teacher 4 (Int1, p.5) was concerned about the knowledge insufficiency. After several teaching weeks, they changed their mind and decided the PET tests could be used and that supported students' better awareness of the whole EAT format (T3, Int2, p.4; T4, Int2, p11)

Another interesting point found out from the data was Teacher 1 thought she could ask her students to bring their own materials to class. For example, she would require them to bring the family photo to class for the speaking lesson of describing a picture. She believed that this facilitated active learning and personalised the lesson, so that the students could have a better engagement sense. By contrast, Teacher 3 and Teacher 4 might spend time designing their own teaching materials for the students.

Table 2 illustrates the teachers' diverse beliefs of the instructional sources under the influence of the EAT. From the literature review (see 2.5), most researchers found teachers' dissatisfaction with the teaching materials they had for the course (Antineskul \& Sheveleva, 2015; Hsu, 2009; Thuy Nhan, 2013; Tran, 2016). Only two authors, 
Nguyen (2017) and Saif (2009), express their respondents' positive beliefs of the materials in use. The findings from this research provide a bright sign for washback to teachers' perceptions under the EAT at the university. All the teachers believed that the book totally fit their students' needs of passing the exam and communication. No blames on the course book were found. Only a few supplementary materials were needed to motivate students. This finding was in contrast to other researchers' when the teachers needed more materials to support their students. This can be explained by the test nature; all the test in the research, except BEC (Antineskul \& Sheveleva, 2015), are highstake. Here again the total frequency of teachers' words of course materials was in cohesion with that of course objectives (4.1) with Teacher 1 at the top and Teacher 4 at the bottom.

Table 2. Frequency of the teachers' words related to the teaching sources

\begin{tabular}{|c|c|c|c|c|}
\hline Words & T1 & T2 & T3 & T4 \\
\hline Complete PET & 19 & 15 & 6 & 7 \\
\hline PET 1-8 & 1 & 2 & 1 & 4 \\
\hline Online sources & 1 & 2 & 0 & 0 \\
\hline Student-prepared materials & 1 & 0 & 0 & 0 \\
\hline Teacher-designed sources & 0 & 0 & 1 & 1 \\
\hline TOTAL & 22 & 19 & 8 & 12 \\
\hline
\end{tabular}

4.3. The washback of the EAT on the teachers' perceptions of the teaching topics

The book Complete PET has 12 units, but the syllabus narrows it down to eight units from one to eight. According to Pan (2009), reducing the number of the topics is one type of negative washback. The researcher looks for the teachers' thought of either topic reduction or extension and the underlying reasons for such views.

All the four teachers agreed that the topics they had to teach in class were predetermined by the division and they were exactly the topics the students would be tested in the exam (T1, Int1, pp.5-6; T2, Int1, p.5, Int2, p.13; T3, Int2, p.3; T4, Int1, p.4; Int2, p.7). However, Teacher 2 was inclined towards topic extensions for the reading skill.

"Regarding the speaking skill, writing skill and listening skill, <the topics> are the same. However, there were differences in reading skills. In oder to have correct answers in the reading skills, the students have to have more knowledge, not only around the topics. If the students learn that way $<$ the topic only $>$, they are limited. They have to upgrade a bit more." (Int2, p.13)

Teacher 4 was in alignment with Teacher 2 in extending the topics for the students if her students need (Int2, p.7)

Teacher 1 was more practical to base on the test stake to state,

"We don't teach all the things in the book. Especially the EAT is only a transformation of the PET, an equivalent. Therefore, the requirement is lower than the international PET [.... When we design the test, we determine that what we test is what the students learn, so the topics we deliver to the students, set in the syllabus, are those for the test [...] It <topic extension> must be hard because their entrance ability is not as we expect, A2 level. Many students are under that level. So topic extensions are not possible [...] As I have said we do not have time. [...] Then we teach the PET format. The 
teacher can guide the students to do relevant exercises. I think the topic can be extended but in a large class, for example of 60 students, we are hard to cover them." (Int2, pp.3-6)

She did not think she taught all the things in the topics because the EAT was downsized from the PET. Other affecting factors were the students' low ability, the limited time allowance and the large class were repeated like the conclusion in 4.2.2.1.

When the teachers' perceptions were compared to their practices, the class observations showed that all the teachers followed the textbook strictly.

The findings from the data reveal that the teaching materials were in line with the proposed models by Bachman and Palmer (1996), Bailey (1999), Green (2007) and Shih (2009). Topic reduction is considered negative washback (Pan, 2009; Shohamy,
1996; Bachman, 2010, Alderson \& HampLyons, 1996; Wall, 2005, Watanabe, 1996). However, concerning the contextual factors like the students' ability, the time allocation, and the test stake, such downsize is reasonable. It enables the teachers to focus on the teaching contents in the limited timeframe (Bachman (1990), Messick (1996), and Turner (2006, cited in Wang, 2010). The textbook was updated like in the case reported by Wall and Horák (2011) and Nguyen (2017). Another shining point lied in the teachers' positive attitude toward the textbook contents, which is similar to the results in Saif (2006), Nguyen (2007). Little evidence of material development and extension was found as Hughes (1993), Nguyen (2017) call out for the nature of the achievement test. Strong washback to teaching contents was assured when the textbook illustrated the test contents.

Table 3. Frequency of the teachers' words related to the teaching topics

\begin{tabular}{|c|c|c|c|c|}
\hline Words & T1 & T2 & T3 & T4 \\
\hline Topics reduced due to restricted course time & 2 & 4 & 2 & 1 \\
\hline Topics reduced due to student low proficiency & 3 & 0 & 1 & 1 \\
\hline Topics reduced due to large classes & 1 & 0 & 0 & 0 \\
\hline Topics? reduced due to the relevance to the EAT & 0 & 0 & 1 & 0 \\
\hline Topics? related to the EAT topics & 0 & 0 & 2 & 1 \\
\hline Topics? extended to improve students' learning & 1 & 1 & 0 & 1 \\
\hline Total & 7 & 5 & 6 & 4 \\
\hline
\end{tabular}

With respect to the topics, no explicit words in previous review were called out; nonetheless, it is an integral part of the teaching contents. This research finding shows that the words pertaining to topics occurs less frequently than those to objectives and materials. Teacher 1 still owned the highest frequency and Teacher 3 was opposite to Teacher 1 (See Table 1, Table 2).

The following figure visualises the EAT washback on the teachers' perception of the teaching contents in English 2.

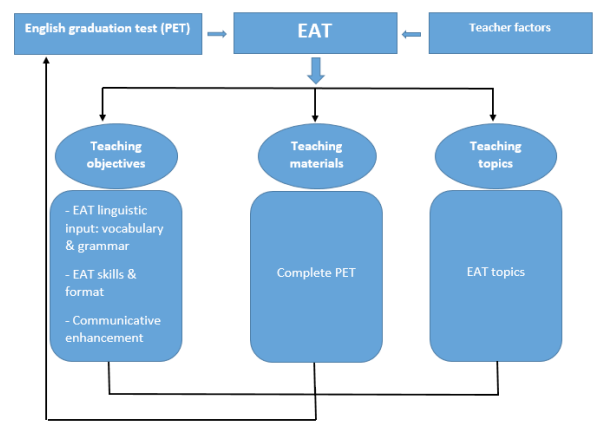

Figure 1. EAT washback to teachers' perceptions of teaching contents 


\section{Conclusion and pedagogical implication}

The findings from the research suggested that the EAT made significant impacts on teachers' perceptions of the course contents, embracing the course objectives, materials and topics. Teachers' background had a meaning to different perception degrees.

The case was compelling because the EAT was embedded in the PET as an English graduation test for the undergraduates at the researched university. Normally an EAT is low stake. According to Alderson and Wall (1993), no washback is expected in such tests. The findings proved the opposite fact. The teaching objectives were obviously known to all the teachers, followed by the teaching materials and the teaching topics. There was a mismatch between the university expectations from the course and the teachers' perceptions of the course objectives. Communicative ability upgrading was anticipated in the course. The university hopes their undergraduates can survive well in the modern world of work with their English competencies. However, almost all the teachers thought the course goal was the students' passing rate, so they tried to equip them with the test knowledge, skill and format. Few ideas of raising the communication ability were found out. Concerning the materials, all the teachers were in favour of the course book, which directly served the exam contents. The book contained a variety of topics, but the teachers chose the topic narrowing as stated in the syllabus. Pan (2009) may call this either a negative or positive impact of the test, depending on the communicative ability gain from teaching. If this restriction allows students to acquire knowledge and be able to apply it in the real life context, the washback should be viewed as beneficial. It is opposite if students can only do well in the test. According to the research findings, communication is one test objective. This research is limited in the sense that it views teachers' perceptions, not practices; therefore, researchers should be more careful to reach the conclusion of the actual washback. Regarding teacher factors, the teachers who took more accountability to the student success showed the most impact degree. The current study is meaningful in that it provides the explicit course objectives in teachers' thoughts, from which policy makers and leaders can come to suitable administration policies.

The research leaves research gaps for further studies. The first gap lies in the number of participants. More teachers should participate in such research to release a wider data range. Secondly, triangulation methods can be applied, for example, with surveys and class observations contributing to the research validity. Thirdly, other aspects of washback of the EAT to teachers' perceptions like methodology, professional development will be for further studies.

\section{References}

\section{Vietnamese}

Cao Thanh (2018). 85\% sinh viên không đạt chuẩn đầu ra tiếng Anh. Nhân dân điện tủ. Retrieved from https:// www.nhandan.com.vn/giaoduc/item/38571202-85sinh-vien-khong-dat-chuan-dau-ra-tieng-anh.html

Hà Thị Bích Loan (2015) Chuẩn tiếng Anh đầu ra hệ đại hoc chính quy: Thưc trạng và giải pháp. Retrieved from http://nnkt.ueh.edu.vn/index.php/article/chuantieng-anh-dau-ra-he-dai-hoc-chinh-quy-thuc-trangva-giai-phap/es\&sid=ProQ:ProQuest + Education + Jo urnals\&atitle $=\&$ title $=\mathrm{A}+$ study + of $+\mathrm{t}$

Huy Lân (2019). Khó với tới chuẩn đầu ra tiếng Anh. Nguoòi lao động. Retrieved from https://nld.com.vn/ giao-duc-khoa-hoc/kho-voi-toi-chuan-dau-ra-tienganh-20191001212012405.htm

Nguyễn Thị Linh (2017). Một số tác động của bài thi đánh giá năng lực tiếng Anh theo chuẩn đầu ra đối với việc dạy tiếng Anh tại trường Đại học Ngoại ngữ - Đại học Quốc gia Hà Nội. VNU Journal of Foreign Studies, 33(4), 122-136. https://doi.org/https://doi. org/10.25073/2525-2445/vnufs.4177

Thủ tướng Chính phủ (2008). Quyết địn 1400/QĐTTg về viẹc phê duyệt đề án "Day và học ngoại ngũ trong hệ thống giáo duc quốc dân giai đoạn 2008 2020". Retrieved from huvienphapluat.vn/van-ban/ Giao-duc/Quyet-dinh-1400-QD-TTg-phe-duyet-dean-day-va-hoc-ngoai-ngu-trong-he-thong-giao-ducquoc-dan-giai-doan-2008-2020-71152.aspx 


\section{English}

Alderson, J. C., \& Wall, D. (1993). Does washback exist? Applied Linguistics, 14(2), 115-129. https:// doi.org/10.1093/applin/14.2.115

Alderson, J. Ch., \& Banerjee, J. (2002). Language testing and assessment (Part 2). Language Teaching, 35(02), 79-113. https://doi.org/10.1017/ S0261444802001751

Antineskul, O., \& Sheveleva, M. (2015b). Teachers' Perceptions Towards BEC Exams in Russia: A Qualitative Study. Humanities. https://doi. org/10.2139/ssrn.2700624

Bachman, L. F. (2000). Modern language testing at the turn of the century: Assuring that what we count counts. Language Testing, 17(1), 1-42. https://doi. org $/ 10.1177 / 026553220001700101$

Bachman, L. F., \& Palmer, A. S. (1996). Language Testing in Practice: Designing and Developing Useful Language Tests. Oxford Applied Linguistics. https://doi.org/10.2307/328718

Bailey, K. M. (1999). Washback in Language Testing. Education Journal. New Jersey: Educationer Testing Service, Princeton, New Jersey, RM-99-4. https://doi.org/10.11648/j.edu.20150401.12

Barnes, M. (2016). The Washback of the TOEFL iBT on English Language Programs in Vietnam. Australian Journal of Teacher Education, 41(7), 246. https:// doi.org/10.14221/ajte.2016v41n7.10

Barnes, M. (2017). Washback: Exploring what constitutes "good" teaching practices. Journal of English for Academic Purposes, 30, 1-12. https:// doi.org/10.1016/j.jeap.2017.10.003

Borg, S. (2003). Teacher cognition in language teaching: A review of research on what languae teachers think, know, believe, and do. Language Teaching, 36(2), 81-109. https://doi.org/10.1017/ S0261444803001903

Brown, H. D., \& Abeywickrama, P. (2010). Language Assessment: Principles and Classroom Practices, 2nd ed. Upper Saddle River, N.J.; Harlow: Pearson Education.

Buehl , M. M., \& Fives, H. (2009). Exploring teachers' beliefs about teaching knowledge: Where does it come from? Does it change? The Journal of Experimental Education, 77, 367-407.

Bui, T. S. (2016). The Test Usefulness of the Vietnam's College English Entrance Exam. Korea University, Seoul.

Bullock, N. (2017). Learning \& Testing Alignment Towards Positive Washback. Dubrovnik.

Cheng, L. \& Curtis, A. (2012). Test impact and washback: Implications for teaching and learning. In S. Coombe, Christine; Davidson, Peter; O'Sullivan, Barry; Stoynoff (Eds.), The Cambridge Guide to Second Language Assessment. New York: Cambridge University Press.
Cheng, L., Watanabe, Y., \& Curtis, A. (2004). Washback in Language Testing: Research Contexts and Methods. (L. Cheng, Y. Watanabe, \& A. Curtis, Eds.). New Jersey: Lawrence Erlbeaum Associates, Publishers. https://doi.org/10.4324/9781410609731

Cheng, L., Sun, Y., \& Ma, J. (2015). Review of washback research literature within Kane's argument-based validation framework. Language Teaching, 48(4), 436-470. https://doi.org/10.1017/ S0261444815000233

Cohen, A. D. (1994). Assessing Language Ability in the Classroom. Heinle \& Heinle Publishers.

Council of Europe. Common European Framework Reference for Languages: Learning, Teaching, Assessment. Cambridge University Press/Council of Europe.

Creswell, J. W. (2003). Research Design: Qualitative, Quantitative, and Mixed Methods Approaches. California: Sage Publications. https://doi.org/10.31 09/08941939.2012.723954

Dinh, M. T. (2019). Developing a washback framework of English tests to teachers' perceptions and practices. Proceeding of the International Graduate Research Symposium. pp. 757-767. Vietnam National University Press, Hanoi.

Duff, P. A. (2008). Case Study Research in Applied Linguistics. New York, NY: Lawrence Erlbaum Associates.

Green, A. (2013). Washback in language assessment. International Journal of English Studies, 13(2), 39-51.

Hsu, H. F. (2009). The impact of implementing English proficiency tests as a graduation requirement at Taiwanese universities of technology. University of York. Retrieved from http://etheses.whiterose. ac.uk/576/

Hughes, A. (2003). Testing for Language Teachers. Australian Review of Applied Linguistics (Vol. 27). https://doi.org/10.1017/CBO9780511732980

Liauh, Y. H. E. (2011). A study of the perceptions of English faculty and students of Exit English Examinations at Taiwan's technological and vocational higher education institutions. Thesis. University of Montana. Retrieved from http://search.proquest.com/docview/ 874150865 ?accountid $=14548 \% 5 \mathrm{Cnhttp}: /$ metadata. lib.hku.hk/hku?url_ver=Z39.88-2004\&rft_val_ fmt=info:ofi/fmt:kev:mtx:dissertation\&genre $=\overline{\text { dissert }}$ ations $+\% 26+$ theses\&sid=ProQ:ProQuest+Education + Journals\&atitle $=\&$ title $=\mathrm{A}+$ study $+\mathrm{of}+\mathrm{t}$

Le, V. C. (2011). Form-Focus instruction: A case study of Vietnamese teachers' beliefs and practices. Applied Linguistics, $\mathrm{PhD}$ Thesis.

McNamara, T. (2000). Language Testing.pdf. Oxford, UK: Oxford University Press.

Messick, S. (1996). Validity and washback in language testing. Language Testing. Retrieved from http://1tj. sagepub.com/content/13/3/241.short 
Nguyen, P. N. (1997). Washback effects of international English language testing system at the Vietnam National University. University of Melbourne, Oppenheim.

Nguyen, T. L. (2017). Impacts of Vietnamese standardised test of English proficiency on the first year students' English language learning. Đề án Ngoại ngũ Quốc gia 2020. Retrieved from https://dean2020.edu.vn/vi/ news/Tin-tuc/impacts-of-vietnamese-standardizedtest-of-english-proficiency-vstep-on-the-first-yearstudents-english-language-learning-410.html

Onaiba, A. M. E. (2013). Investigating the Washback Effect of a Revised EFL Public Examination on Teachers' Instructional Practices, Materials and Curriculum. Leicester: University of Leicester.

Pajares, M. F. (1992). Teachers' beliefs andd educational research: Cleaning up a messy construct. Review of Educational Research, 62(3), 307-322.

Paker, T. (2012). The Backwash Effect of the Test Items in the Achievement Exams in Preparatory Classes. Procedia Social and Behavioral Sciences, 70, 1463-1471. https:// doi.org/10.1016/j.sbspro.2013.01.212

Pan, Y. (2009). A review of washback and its pedagogical implications. VNU Journal of Science, Foreign Languages, 25(February), 257-263.

Pearson, I. (1988). Tests as levers for change. In Chamberlain, D. and Baumgarten, R. (Eds.), ESP in the classroom: Practice and Evaluation (pp. 98107). Oxford: Modern English Publications,

Pierce, B. (1992). Demystifying the TOEFL reading test, TESOL Quarterly, 26(4), 665-689.Shohamy, E. (1993). The power of tests : The impact of language tests on teaching and learning. NFLC occasional paper. The National Foreign Language Center, 1-20. Retrieved from https://eric.ed.gov/?id=ED362040

Read, J., \& Hayes, B. (2003). The Impact of IELTS on Preparation for Academic Study in New Zealand. IELTS Research Reports (Vol. 4). Canberra.
Retrieved from https://search.informit.com.au/docu mentSummary; dn=909013632781357;res=IELHSS

Saif, S. (2006). Aiming for positive washback: a case study of international teaching assistants. Language Testing, 23(1), 1-34. https://doi. org/10.1191/02655322061t322oa

Shih, C.-M. (2007). A New Washback Model of Students' Learning. Canadian Modern Language Review, 64(1), 135-161. https://doi.org/10.3138/ cmlr.64.1.135

Thuy Nhan. (2013). The TOEIC ${ }^{\circledR}$ Test as an Exit Requirement in Universities and Colleges in Danang City, Vietnam: Challenges and Impacts. International Journal of Innovative Interdisciplineary Research, 2(June), 33-50.

Tran, T. D. (2016). Impact of using TOEIC as an exit requirement at a public university in Vietnam. In 4th British Council New Directions in English Language Assessment: Standardised Testing and Proficiecy Scales. Retrieved from https://www.britishcouncil. vn/sites/default/files/new_directions_2016_dr duyen_tran_impact_of_using_toeic_as_an_exit requirement_at_a_public_university_in_vietnam.pdf

Wall, D., \& Horák, T. (2006). The Impact of Changes in the TOEFL Examination on Teaching and Learning in Central and Eastern Europe: Phase 1, The Baseline Study. University, UK.: EST.

Wang, J. (2010). A Study of the Role of the "Teacher Factor" in Washback. McGill University, Montreal.

Watanabe, Y. (2004). Methodology in Washback Studies. In C., Liying, W., Yoshinori \& A., Curtis (Eds.), Washback in Language Testing: Research Context and Method (pp.19-26). Marwah, New Jersey: Lawrance Erlbaum Associates, Inc. Publishers. 


\title{
TÁC ĐộNG DỘI NGỰ̛̣C CỦA BÀI THI HẾT HỌC PHẦ LÊN NHẬN THỨC CỦA GIÁO VIÊN TẠI MỘT TRƯỜNG ĐẠI HỌC Ở VIẸTT NAM
}

\author{
Đinh Minh Thu \\ Đại học Hải Phòng, \\ 171 Phan Đăng Luu, Kiến An, Hải Phòng, Việt Nam
}

Tóm tắt: Có nhiều nghiên cứu về tác động dội ngược vào lớp học của các bài thi có tính quyết định cao. Tuy nhiên, có ít nghiên cứu chú ý tới tác động dội ngược này của các bài thi cuối khóa (EAT) dù các bài thi này có ý nghĩa thực tiễn cao, ví dụ như thông báo và nâng cao hiệu quả giảng dạy của giáo viên ngay trong chương trình học tại một cơ sở giáo dục cụ thể (El-Kafafi, 2012; Antineskul \& Sheveleva, 2015). Mục đích của bài viết này là nghiên cứu tác động dội ngược của một bài thi cuối khóa (EAT) lên nhận thức của giáo viên về mục tiêu của khóa học và tài liệu giảng dạy trong lớp học. Khóa học này có ý nghĩa tương đối quan trọng, như là bước đệm cho sinh viên bước vào bài thi $\mathrm{PET}$ đo chuẩn đầu ra chính thức trình độ $\mathrm{B} 1$ tại môt trường đại học ở Việt Nam theo yêu cầu của Bộ Giáo dục và Đào tạo. Cấu trúc bài thi EAT dựa trên bài thi PET. Công cụ nghiên cứu là phỏng vấn bốn giáo viên cùng giảng dạy khóa học này. Mỗi giáo viên được phỏng vấn hai lần để tác giả có thể ghi lại sự tiến triển nhận thức trong quá trình giảng dạy. Kết quả nghiên cứu chỉ ra bài thi tác động mạnh mẽ tới nhận thức của giáo viên về mục tiêu và nội dung giảng dạy. Hai kết quả nổi bật là: (1) tất cả các giáo viên đều đồng ý rằng mục đích khóa học phục vụ định hướng thi cử hết khóa và cả bài thi PET, đặc biệt về dạng bài thi và nguồn ngôn ngữ, (2) giáo viên nên tuân thủ chặt chẽ giáo trình. Có sự lệch pha giữa mục đích nâng cao năng lực giao tiếp của người học với nhận thức thực tế của giáo viên về việc học để thi. Sự khác biệt về kiến thức, kinh nghiệm nền tảng của các giáo viên dẫn đến sự khác biệt về nhận thức. Kết quả nghiên cứu phục vụ như nguồn tham khảo cho các độc giả trong và ngoài bối cảnh nghiên cứu.

Tù khóa: tác động dội ngược, bài thi tiếng Anh cuối khóa, nhận thức của giáo viên

\section{Appendix - Interview guideline of teachers' perceptions of teaching contents}

\begin{tabular}{|l|l|}
\hline \multicolumn{1}{|c|}{ ASPECTS } & \multicolumn{1}{c|}{ QUESTIONS } \\
\hline 1. Course objectives & $\begin{array}{l}\text { 1. What is your actual teaching objective in Course English 2? How do you think } \\
\text { about the combination between the teaching objective of Course English } 2 \text { and } \\
\text { the objective of the final English achievement test (EAT) of the course? Why? } \\
\text { 2. Do you reach the test objective in every lesson or some lessons? Why? }\end{array}$ \\
\hline 1 2. Teaching sources & $\begin{array}{l}\text { 1. The teaching material for the course is Complete PET. The test materials are } \\
\text { Complete PET and PET tests. What materials do you use ? Why? } \\
\text { 2. How do you evaluate Complete PET in relevance with the EAT? } \\
\text { 3. Do you teach all the parts in the textbook or select some parts ? What parts do } \\
\text { you select? } \\
\text { 4. Do you use supplementary materials in teaching to meet the objective(s) of the } \\
\text { EAT ? If yes, what are they? }\end{array}$ \\
\hline 1.3. Topics & $\begin{array}{l}\text { 1. Are the topics of Complete PET the same as those of the EAT? } \\
\text { 2. Do you think you should cover all the topics in Complete PET? Why (not)? } \\
\text { 4. Dow can the topics server students' learning? } \\
\text { 5. How can the topics help the EAT? }\end{array}$ \\
\hline
\end{tabular}

